Western Washington University

Western CEDAR

\title{
Reasoning about Institutional Change: Winners, Losers and Support for Electoral Reforms
}

Todd Donovan

Western Washington University, todd.donovan@wwu.edu

Shaun Bowler

Follow this and additional works at: https://cedar.wwu.edu/politicalscience_facpubs

Part of the Political Science Commons

\section{Recommended Citation}

Donovan, Todd and Bowler, Shaun, "Reasoning about Institutional Change: Winners, Losers and Support for Electoral Reforms" (2007). Political Science Faculty Publications. 7.

https://cedar.wwu.edu/politicalscience_facpubs/7 


\section{CAMBRIDGE UNIVERSITY PRESS}

Reasoning about Institutional Change: Winners, Losers and Support for Electoral Reforms Author(s): Shaun Bowler and Todd Donovan

Source: British Journal of Political Science, Vol. 37, No. 3 (Jul., 2007), pp. 455-476

Published by: Cambridge University Press

Stable URL: http://www.jstor.org/stable/4497303

Accessed: 23/10/2014 16:48

Your use of the JSTOR archive indicates your acceptance of the Terms \& Conditions of Use, available at http://www.jstor.org/page/info/about/policies/terms.jsp

JSTOR is a not-for-profit service that helps scholars, researchers, and students discover, use, and build upon a wide range of content in a trusted digital archive. We use information technology and tools to increase productivity and facilitate new forms of scholarship. For more information about JSTOR, please contact support@jstor.org. 


\title{
Reasoning About Institutional Change: Winners, Losers and Support for Electoral Reforms
}

\author{
SHAUN BOWLER AND TODD DONOVAN*
}

\begin{abstract}
This study assesses how the mass public reasons about political institutions by examining the effects of winning and losing on support for several electoral reform proposals. The national sample survey identified majorities supporting proposals for major changes in America's electoral institutions, and that suggested electoral losses may have a modest effect in reducing losers' satisfaction with how democracy works. Random assignment experiments that tested hypotheses derived from theories of risk perception were conducted. It was found that people who saw themselves as winners and losers in the electoral arena reasoned differently when proposals for change were framed in terms of loss. Losers may be just slightly more supportive than winners of some electoral reforms; however, they appeared less sensitive than winners to framing effects that presented reform proposals in terms of the risks of loss. Winners may support the same reform proposals but their support for change decreased more when the proposals were framed as a potential loss. Winners are thus risk aversive when evaluating electoral reform proposals, while losers may even be risk seeking. Although this survey found support for major reforms, the patterns of reasoning that were identified in the mass public suggest a basis for the stability of electoral institutions.
\end{abstract}

The stability of electoral institutions is often explained in terms of incumbent elected officials' self-interest in preserving status quo rules. ${ }^{1}$ Yet electoral systems do change on occasion in response to popular support for reforms from people who voted for the losers. Major changes in the Italian election system were forced on established party incumbents in 1993 by 'outsiders' using the referendum process. ${ }^{2}$ Likewise, support from voters aligned with parties out of government was a significant factor in passing a 1993 electoral reform referendum that changed New Zealand's voting system from first-past-the-post (FPTP) to Mixed Member Proportional. ${ }^{3}$

Major electoral system change is a rather rare event, nonetheless, with the United States providing an example of enduring electoral rules that can produce controversial outcomes. America's FPTP legislative elections awarded Republicans control of a majority of seats elected in 2004 to both the House and Senate, although Democrats won more votes in House and Senate races that year. Most voters were on the losing side of three consecutive presidential elections prior to 2004, and the selection of Florida's decisive presidential electors in 2000 was particularly acrimonious. As we show in this article, proposals for

\footnotetext{
* Department of Political Science, University of California, Riverside; and Department of Political Science, Western Washington University, respectively. Equal co-authors. Earlier versions of this article were presented at Midwest Political Science Association meetings. The authors thank the Rice University and Texas Tech University political science departments for opportunities to present this research, and thank Skip Lupia and Diana Muntz for their efforts with the Time-sharing Experiments for the Social Sciences (TESS). Data used in this study are available at http://www.experimentcentral.org/data/. Direct correspondence to T. Donovan, Department of Political Science, Western Washington University, Bellingham, WA, 9825, USA.

' Kenneth Shepsle, 'A Comment on Institutional Change', Journal of Theoretical Politics, 13 (2001), 321-5.

$\rightarrow$ Mark Donovan, 'The Politics of Electoral Reform in Italy', International Political Science Review, 16(1995), 47-64.

$\rightarrow$ Susan Banducci and Jeffrey Karp, 'Perceptions of Fairness and Support for Proportional Representation', Political Behavior, 21 (1999), 217-38.
} 
major electoral reforms do receive considerable public support in the United States. Despite all this, the fundamental processes by which Congress and the president are elected (single-member districts and the Electoral College) have proven to be resistant to major change. This phenomenon is not unique: in Britain and Canada, a majority of voters regularly cast ballots against the party that wins control of government while many proposals for reforming electoral systems languish. This suggests a bit of a paradox: if proposals for change are relatively popular and most voters are often on the losing side of major elections, why are established electoral institutions so stable?

We study this paradox at the level of the voter by examining how electoral winners and losers reason about institutional change. ${ }^{4}$ The long-run resilience of representative democracy requires that those who lose in the electoral arena share some basic commitment to maintaining democratic institutions. People who support winners and losers in elections may see electoral institutions differently, and institutions, as North notes, are the 'rules of the game' that structure a society. ${ }^{5}$ Recent scholarship underscores the important relationships between electoral loss and attitudes about democratic institutions. ${ }^{6}$ Other research has made important strides in advancing our understanding of how citizens evaluate democratic institutions. ${ }^{7}$ Here we bridge these literatures by considering how responses to electoral loss and losing shape citizen reasoning about democratic institutions. This study is an attempt to build on our understanding of how people make choices about institutions, a project that Nobel-laureate Douglass North argues is perhaps the fundamental question we must address in order to make further progress in the social sciences. ${ }^{8}$

The article is divided into three broad sections. In the first section, we discuss the relationship between political institutions and loss, setting out hypotheses that relate to citizen attitudes towards institutional change. In the second section, we present experimental evidence that addresses these hypotheses. We present two types of experiments; one where we prompt people to consider how often candidates they support win and lose in order to test the effects of winning and losing on their assessments of how well democracy works. We show that considerations of losing may have a modest effect on depressing satisfaction with democracy. We then present a series of experiments where we prompt people to consider risks associated with adopting electoral reforms. In most of these experiments, people who perceive themselves as electoral losers are less risk aversive

${ }^{4}$ Others have presented theoretical explanations of the stability of democratic institutions based on the motives of elites. See Adam Prezworski, Democracy and the Market (New York: Cambridge University Press, 1991); Shepsle, 'A Comment on Institutional Change'. Our goal here is to develop an alternative if complementary understanding of this phenomenon based on an understanding of the mass public.

${ }^{5}$ Douglass North, Institutions, Institutional Change and Economic Performance (Cambridge: Cambridge University Press, 1990).

${ }^{6}$ Christopher J. Anderson, André Blais, Shaun Bowler, Todd Donovan and Ola Listhaug, Losers' Consent: Elections and Democratic Legitimacy (Oxford: Oxford University Press, $20 r^{\circ} \rightarrow$ Christopher J. Anderson and Christine Guillory, 'Political Institutions and Satisfaction with Democracy', American Political Science Review, 91 (1997), 66-81; Jeffrey Karp and Susan Banducci, 'To Know It Is to Love It? Satisfaction with Democracy in the European Union', Comparative Political Studies, 36 (2003), 271-92.

${ }^{7}$ Max Kaase and Kenneth Newton, Beliefs in Government (Oxford: Oxford University Press, 1995); Hans-Dieter Klingermann and Dieter Fuchs, Citizens and the State (Oxford: Oxford University Press, 1995); Pippa Norris, Critical Citizens: Global Support for Democratic Governance (Oxford: Oxford University Press, 1999).

${ }^{8}$ Douglass North, 'Nobel Laureate Lecture', Les Prix Nobel (Stockholm: Nobel Foundation, Royal Swedish Academy of Sciences, 1993). 
than winners, and winners are more risk averse than losers. In the final section, we draw out the implications of these findings for democratic institutions more broadly.

\section{POLITICAL INSTITUTIONS AND LOSING}

Many studies of legitimacy in democratic societies assess attitudes towards current institutions by examining levels of satisfaction with democracy, or trust in government. ${ }^{9}$ Democracies may remain stable and be seen as legitimate by citizens as long as political minorities who lose are willing to remain committed to playing the game of electoral politics. ${ }^{10}$ Acceptance of the existing rules of the game may erode, however, among those who lose, and especially among those who lose repeatedly. Repeat losers are, furthermore, more likely to begin to think about changing the rules. ${ }^{11}$ Our approach to assessing support for changing political institutions is to see how perceptions of electoral losses affect how people evaluate proposals to alter electoral institutions. We seek to determine if perceptions of losses affect how people evaluate the way democracy works, and to assess how electoral winners and losers reason about changing democratic institutions.

Satisfaction with how democracy is working is one standard measure of mass attachments to current electoral institutions. Another, more telling, measure of this is the public's willingness to change their current democratic institutions and support alternative arrangements. A willingness to change may be seen as a sign of how discontented people really are with their current institutions. One of the major questions of interest below is the degree to which being a 'loser' in an electoral sense pushes people into changing rules about how elections and representation work. We suggest that when people are presented with alternative institutional arrangements their choices may be informed by some level of self-interest: winners may be disposed towards preserving institutional rules under which they won, while losers may be likely to want to make new electoral rules that are favourable to them. Losers, wanting to become winners, may support rule changes that offer the promise of making them winners or giving them more influence over policy making. ${ }^{12}$ If ordinary citizens reason like this, we should see that losers are more likely than winners to support proposals for institutional change.

This is a relatively straightforward argument to make when discussing political elites, and a few studies have provided evidence in its support in that context. ${ }^{13}$ The novelty here is in applying such an argument to the mass public, and the evidence we present below speaks to how well such a model of rational calculation may explain how ordinary citizens view political institutions. The argument can be extended to consider the different ways that institutional changes may be framed. Any real-world institutional change is likely to be quite complicated and have a number of different consequences. In presenting people

9 Ola Listhaug, 'The Dynamics of Trust in Politicians', in Hans-Dieter Klingermann and Dieter Fuchs, eds, Citizens and the State (Oxford: Oxford University Press, 1995), pp. 261-98; Karp and Banducci, 'To Know It Is to Love It? Satisfaction with Democracy in the European Union'; Norris, Critical Citizens: Global Support for Democratic Governance; Kaase and Newton, Beliefs in Government.

10 Anderson and Guillory, 'Political Institutions and Satisfaction with Democracy'; Listhaug, 'The Dynamics of Trust in Politicians'.

11 William Riker, The Art of Political Manipulation (New Haven, Conn.: Yale University Press, 1986).

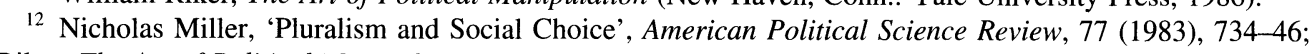
Riker, The Art of Political Manipulation.

${ }^{13}$ For exam $\rightarrow$, Kathleen Bawn, 'The Logical of Institutional Preferences: German Electoral Law as a Social Choice Outcome', American Journal of Political Science, 37 (1993), 965-89. 
with proposals for electoral system changes it is possible to emphasize some potential consequences over others, and to stimulate different modes of reasoning about institutions by changing question wording in survey experiments. One way that consequences of institutional changes may be framed is in terms of risks and losses. Institutions determine who winners and losers are, and are thus 'distributional' in nature either very often ${ }^{14}$ or all the time. ${ }^{15}$ Losses (or gains) that may be incurred as a result of the change are thus central to questions about institutional change. In our experimental setting we frame questions about institutional change in neutral terms or with positive language, and then contrast the effects of such framing with similar questions framed to present the change in terms of a risk or loss.

\section{EXPERIMENTS ON LOSING AND SUPPORT FOR INSTITUTIONAL CHANGE}

Our experimental design includes four conditions to consider when thinking about how people might respond to proposals calling for institutional reforms. These are:

(a) current winners under status quo institutions who are presented with an alternative arrangement where risk is not emphasized,

(b) current losers under status quo institutions who are presented with an alternative arrangement where risk is not emphasized,

(c) current winners under status quo institutions who are presented with an alternative arrangement where risk is emphasized, and

(d) current losers under status quo institutions who are presented with an alternative arrangement where risk is emphasized.

We test how citizens reason about democratic institutions by offering them alternative versions of four electoral reform proposals, where the alternative versions frame the consequences of reforms differently - one version of each proposal places no emphasis on risk of loss, while the other version does. Our hypotheses are derived from theories of attitudes towards risk. Experimental psychology has demonstrated that people are more sensitive to the prospect of personal losses than gains in many contexts. ${ }^{16}$ Drawing from this, we expect that proposals for institutional change framed in terms of a risk of loss (conditions (c) and (d) above) will generally receive less support. However, given the discussion in the previous section, we also expect that losers may generally be more supportive of institutional change than winners.

As the Appendix illustrates, our survey included two versions of four distinct questions about electoral reform to re-create conditions (a) through (d) noted above. Respondents to our survey were randomly assigned one of two versions of four questions about changing

14 George Tsebelis, Nested Games: Rational Choice in Comparative Politics (Berkeley: University of California Press, 1990).

${ }_{15}$ Jack Knight, Institutions and Social Conflict (Cambridge: Cambridge University Press, 1992).

$\rightarrow$ Daniel Kahneman and Amos Tversky, 'Prospect Theory: An Analysis of Decision Under Risk', Econometrica, 47 (1979), 263-91; Daniel Kahneman and Amos Tversky, Choices, Values and Frames (Cambridge: Cambridge University Press, $20 \rightarrow$; James Andreoni, 'Warm Glow versus Cold Prickle: The Effects of Positive and Negative Framing on Cooperation in Experiments', Quarterly Journal of Economics, 110 (1995), $1-\rightarrow$. Donald Philip Green, Daniel Kahneman and Howard Kunreuther, 'How the Scope and Method of Public Funding Affect Willingness to Pay for Public Goods', Public Opinion Quarterly, 58 (1994), 49- $\rightarrow$. B. J. McNeil, S. G. Pauker, H. C. Sox and A. Tversky, 'On the Elicitation of Preferences for Alternative Therapies', New England Journal of Medicine, 306 (1982), 1259-62; V. Hueber, M. Neale and G. Northcraft, 'Decision Bias and Personnel Selection Strategies', Organizational Behavior and Human Decisions Processes, 40 (1987), 136-47. 
electoral arrangements in the United States. The questions asked if they supported term limits for Congress, direct election of the president, proportional representation and a national referendum process. Much of the language in each version of the questions was identical except for how the consequences of the proposed reforms were framed. Version A of each question is framed with no reference to any risk of a loss and/or with the use of positive language suggesting the reform would 'give' voters something, produce 'more' of something, or yield some 'gain'. Version B of each question is framed in terms of the potential risk of some kind of loss, and uses negative language to frame the consequences (for example, that something cannot happen if the reform is adopted, that there will be less of something, that something will be undermined or that something will be lost). Our frames may thus be seen as randomly assigning subjects alternative interpretations of the consequences of institutional reforms. Our point is not to frame potential gains or losses associated with institutional change in terms of logical equivalents (as Khaneman and Tversky did), ${ }^{17}$ but to test how people respond to different interpretations of the consequences of electoral reforms.

The literature on the psychology of choice leads us to expect that the effect of the negative stimulus (the risk of losses) may be different across electoral winners and losers. This allows us to develop some specific expectations about the patterns of responses we may see associated with conditions (a) through (d). Results from experiments that simulate monetary gambles illustrate that fear of losses leads subjects to become more risk-seeking in order to avoid loss. ${ }^{18}$ Those who have been losing repeatedly, moreover, become more willing to accept a risky bet. ${ }^{19}$ That is, at some point the default aversion to risk of losses may be overtaken by the effect of losing. Thus, our major question of interest is, are losers less risk averse than winners when reasoning about proposals for changing electoral institutions? Evidence affirming this question would suggest that, at some unknown point, there may be destabilizing effects of electoral rules that create a category of citizens who perceive themselves as chronic losers. Conversely, aversion to risk may well reduce support for institutional change. For example, it may be that concerns about risk make winners especially reluctant to consider changing institutions. In terms of the list of conditions outlined above we expect, among winners, support for change to be higher under condition (a) than condition (c).

A related question considers the other major group under study - to our mind the more interesting one - the losers. A great deal of attention is typically paid to the winners in any political setting. But the losers comprise an important group because their reaction to loss and losing can condition the broader success or failure of the system as a whole. In this case, we consider whether electoral losers are less risk averse or more risk seeking when considering proposals to change institutions. Are losers in the electoral arena somehow less sensitive to risks associated with altering institutions? Winners may be especially risk averse. If they do well under current arrangements then when they are presented with a reform proposal where risks of changing the status quo are stressed, it seems reasonable to suppose they become less likely to support change. But is this necessarily the case for losers? Although we expect losers to be generally supportive of change, is this support also likely to decline once the risks of potential losses associated with change are stressed?

$\rightarrow$ Daniel Kahneman and Amos Tversky, 'Choices, Values, and Frames', American Psychologist, 39 (1984), 341-50.

18 Kahneman and Tversky, 'Choices, Values, and Frames'.

$\stackrel{1 n}{\rightarrow}$ William J. Gehring and Adrian R. Willoughby, 'The Medial Frontal Cortex and the Rapid Processing of Monetary Gains and Losses', Science, 295 (2002), 2279-82. 
A straightforward hypothesis of risk aversion would suggest that, like winners, losers are likely to shy away from the risks of change. Thus, support for change may be lower among winners in condition (c) than winners in condition (a); and lower among losers in condition (d) than losers in condition (b).

However, both theory and empirical findings in the psychology literature lead us to expect that losers are less sensitive to risks of future losses and are thus more willing to gamble with institutional change. That is, we suggest that winners and losers are not likely to have similar responses to current institutions nor are they likely to have similar aversion to the risks of changing those institutions. If this is the case, support for change should be higher among losers exposed to the risk frame (Group C) than among winners exposed to the risk frame (B). Likewise, when winners consider the risk of loss associated with change, those considerations may have a larger effect on reducing their support for change than such considerations of risk have on reducing support among losers. Put differently, the decline in support for electoral reforms across people in (A) and (C) should be greater than the decline in support across people in (B) and (D).

\section{TABLE $1 \quad$ Hypotheses about Levels of Support in Each Group}

\begin{tabular}{lcc}
\hline \hline \multirow{2}{*}{ Stimulus } & \multicolumn{2}{c}{ Respondent's status } \\
\cline { 2 - 3 } & Electoral winner & Electoral loser \\
\hline Electoral reform framed neutral or as gain & $\mathrm{A}$ & $\mathrm{B}$ \\
Electoral reform framed as a loss & $\mathrm{C}$ & $\mathrm{D}$ \\
\hline \hline
\end{tabular}

Note: The hypotheses are: $\mathrm{B}>\mathrm{A}$ (losers are more supportive of change); $\mathrm{A}>\mathrm{C}$ (stimulus of risk/loss decreases support for change for winners); $\mathrm{B}>\mathrm{D}$ (stimulus of risk/loss decreases support for change for losers), but losers are less risk averse than winners, so $C>D$, or $(A-C)>(B-D)$ (effect of risk frame is weaker among losers than winners).

These hypotheses about how electoral losers and winners respond to questions designed to simulate risks associated with changing electoral arrangements are presented schematically in Table 1. Our survey includes three questions designed to construct measures of a respondents' perceptions of their personal electoral losses that allow us to test whether questions framed as risky propositions elicit less support among respondents who perceive themselves as electoral winners than among those who perceive themselves as electoral losers. Here, we assume that perceptions of losing in the electoral arena over a time period may have consequences on attitudes about electoral rules. Our questions about electoral wins and losses thus ask respondents to consider whether candidates they supported 'in their lifetime' usually win or lose.

\section{EXPERIMENTS ON LOSING AND SATISFACTION WITH DEMOCRACY}

Before assessing how winning and losing affect reasoning about democratic institutions, we need to examine how winning and losing might shape how people perceive democracy. We have reasons to expect that losers are likely to be less satisfied with how democracy works. ${ }^{20}$ Scholars have also established that measures of satisfaction with

$\stackrel{n}{\rightarrow}$ Susan Banducci and Jeffrey Karp, 'How Elections Change the Way Citizens View the Political System: Campaigns, Media Effects, and Electoral Outcomes in Comparative Perspective', British Journal of Political Science, 33 (2003), 443-67. 
democracy reflect the effects of political institutions, ${ }^{21}$ short-term effects of specific campaign outcomes, media exposure ${ }^{22}$ and economic conditions. ${ }^{23}$ Our experimental design alternates the position of survey questions asking about electoral losses to test how considerations of electoral losses affect how satisfied citizens report being with the way democracy works.

Previous studies have identified that responses to a survey question can be conditioned by the content of items asked prior to the question. ${ }^{24}$ One way to interpret these 'question order' effects is that a series of questions may shape the context in which people consider a later question, and trigger deeper thought about a subject than whatever ideas were initially at 'the top of their heads at the moment of answering'. ${ }^{25}$ We expect that a series of questions on losing in the electoral arena will stimulate respondents to consider their personal electoral losses when evaluating how well democracy works (see Appendix for the wording of all questions used in this study). We expect that the satisfaction with democracy question - measured with a survey item used frequently in the Comparative Study of Electoral Systems studies ${ }^{26}$ - will elicit less satisfaction among losers if the question is asked immediately after a series of questions about winning and losing. This experiment provides a test of whether people evaluate democracy, at least in part, on whether it would make them a winner or a loser.

\section{DATA AND RESULTS}

Our experiments were conducted as a module on a survey funded by the Timesharing Experiments in the Social Sciences (TESS) project. The national, random-sample survey of 700 adults was conducted by the University of Indiana Survey Research Center in the autumn of $2003 .{ }^{27}$ Apart from an over-representation of women (55 per cent), the sample is broadly representative of the eligible American voting public: about one-third identified as Democrat and one-third as Republican, roughly one-fifth were under age 33 and

${ }^{21}$ Hans-Dieter Klingemann, 'Mapping Political Support in the 1990s: A Global Analysis', in Pippa Norris, ed., Critical Citizens: Global Support for Democratic Government (Oxford: Oxford University Press, 1999), pp. 31-56; Arendt Lijphart, Patterns of Democracy (New Haven, Conn.: Yale University Press, 1999); Anderson and Guillory, 'Political Institutions and Satisfaction with Democracy'.

${ }^{22}$ Banducci and Karp, 'How Elections Change the Way Citizens View the Political System'.

$\stackrel{n}{\rightarrow}$ Harold D. Clarke, Nitish Dutt and Allan Kornberg, 'The Political Economy of Attitudes Toward Polity and Society in Western European Democracies', Journal of Politics, 55 (1993), 998-1021; Anderson and Guillory, 'Political Institutions and Satisfaction with Democracy'.

$\stackrel{\sim}{\rightarrow}$ Paul Abramson, Brian Silver and Barbara Anderson, 'The Effects of Question Order in Attitude Surveys', American Journal of Political Science, 31 (1987), 90 $\rightarrow$ George F. Bishop, Robert W. Oldendick and Alfred Tuchfarber, 'Political Information Processing: Question Order and Context Effects', Political Behavior, 4 (1982), 117-200; Howard Schuman and Stanley Presser, Question and Answers in Attitude Surveys: Experiments on Question Form, Wording, and Context (New York: Academic Press, 1981).

$\stackrel{\sim}{\rightarrow}$ John Zaller and Stanley Feldman, 'A Simple Theory of the Survey Response: Answering Questions vs. Revealing Preferences', American Journal of Political Science, 36 (1992), 579-616.

${ }^{26}$ David Brockington, 'The Paradox of Proportional Representation: The Effect of Party Systems and Coalitions on Electoral Participation', Political Studies, 52 (2004), 469-90; Banducci and Karp, 'How Elections Change the Way Citizens View the Political System'.

27 These 700 interviews came from four survey modules having 2,015 interviews of 7,631 eligible or potentially eligible contact attempts (residential or personal telephone-lines). Our questions appeared first in each module; 28 per cent of all eligible contacts and contacts of unknown eligibility responded (AAPOR RR3); 33 per cent refused, 11 per cent were never available and the eligibility of 26 per cent of contacts was unknown (no answer, always busy, etc.). If contacts of unknown eligibility are excluded, 35 per cent participated, 44 per cent refused, 16 per cent were never available and 3 per cent were excluded due to language problems. 
one-fifth were over 65 , about half the sample had incomes below $\$ 35,000$ and half had incomes greater than this. These respondents are randomly assigned to different categories of treatment in our experiments.

The basic pattern we expect to see is that losers are more supportive of changing electoral arrangements, and that winners and losers reason differently about changing electoral arrangements. How then, might we identify winners and losers in the electoral arena? Existing studies of the effects of electoral losses typically depend on a single election event (often drawn from election study surveys) to define who winners and losers are. ${ }^{28}$ One potential problem with this approach is that it is difficult to distinguish the effects of a single electoral loss from attitudes about a specific government, or from events associated with a specific election. Someone may vote for a party that does not end up in government, but this need not mean that person regularly votes for that party, or for a party that is regularly excluded from government. The election study approach at measuring the effects of losses is thus largely unable to capture the subjective effects of perceptions of long-term electoral losses, or of expectations about future losses.

We designed three questions to measure peoples' experiences with wins and losses more broadly. Multiple questions were needed in part because America's separation of powers and federalism mean that few people will probably think of themselves as categorical losers in the electoral arena at any fixed point in time. Three different questions asked respondents to consider whether candidates they support usually win or usually lose elections. One asked them to reflect on all presidential elections held in their lifetime, another asked them to reflect on all congressional elections held in their lifetime, and a third asked them to 'look ahead' and consider their prospects in future local, state or national elections. Responses to these questions were used to assess how the effects of voters' perceptions of electoral losses affected their support for various electoral reform proposals.

This approach gives us a more subject-defined measurement of losing than exists in other studies, which is particularly important as we expect it is memories and perceptions of electoral loss generally that affect behaviour, as much as actual experience supporting a specific losing candidate. Two disadvantages of this approach, however, are that people tend to develop more favourable attitudes towards winning candidates over time even if they voted for a loser, ${ }^{29}$ and the dynamics of interpersonal comparisons is likely to lead some people to desire to be winners and thus report that they are. Both factors probably lead to over-reporting of winners, which may mute our observed differences between winners' and losers' attitudes and modes of reasoning.

The Computer Assisted Telephone Interview (CATI) survey platform allowed us to use an experimental design that manipulated how institutional change questions were presented to respondents. In particular, it allowed us to frame institutional changes in terms of gains or losses, allowing us to pose and test four hypotheses. We will present evidence addressing the first of these hypotheses via descriptive data, but Hypotheses 2, 3 and 4 are tested with specific question-wording experiments:

HYPOTHESIS 1 Losers will be more supportive of institutional change than winners, regardless of how proposals for institutional change are framed.

\footnotetext{
28 Anderson and Guillory, 'Political Institutions and Satisfaction with Democracy'; Banducci and Karp, 'How Elections Change the Way Citizens View the Political System'.

$\stackrel{\leftrightarrow}{\rightarrow}$ Allan J. Cigler and Russell Getter, 'Conflict Reduction in the Post-Election Period', Western Political Quarterly, 30 (1977), 363-76; Anderson et al., Losers' Consent.
} 
HYPOTHESIS 2 Perceptions of electoral losses will affect how well people think democracy works. Considerations of electoral losses should make people less satisfied with democracy (Experiment 1 below).

HYPOTHESIS 3 When proposals for institutional change are framed in terms of risks of loss, support for institutional change will be lower among all respondents. In the experiments below: $(a)>(c)$ and $(b)>(d)$.

HYPOTHESIS 4 Losers will be less responsive than winners to the effect of framing proposals for institutional changes as a risk of loss. In the experiment below: (c) $>(d)$; or $((a)-(c))>((b)-(d))$.

Despite the close nature of US elections conducted proximate to the time of our survey (Autumn 2003), and the fact that most Americans did not vote for the incumbent president or the party that controlled Congress at the time of our survey, it is noteworthy that relatively few respondents thought of themselves as losers when asked to consider elections they have participated in over the long term. Figure 1 illustrates that between a quarter to a third of respondents said that most of the candidates they supported lost in presidential and congressional elections held in their lifetime. The data also reflect optimism about the future: over 70 per cent expected that candidates they support would win 'most of the time' in future elections. Furthermore, there are relatively few who perceive themselves as chronic losers in the electoral arena. That is, only 7 per cent of respondents fell into the loser category across all three questions represented in Figure 1, and only 22 per cent fell into the loser category on at least two of the three questions. In contrast, 46 per cent fell into the winner categories on three questions, and another 32 per cent fell into the loser category on only one of the three questions.

At this point, we can only speculate about how accurately these perceptions of winning and losing match reality in the United States. As Wright has shown, ${ }^{30}$ survey respondents probably over-estimate their tendency to support winning candidates. We also expect that many Americans really are on the winning side of most elections they vote in, due to the fact that most Americans live in partisan gerrymandered US House districts where huge majorities vote for the congressional candidate of the dominant party in the district. Or we might assume that it only takes a couple of wins in any election for people to think of themselves as winners over the long haul. That is, people might discount losses in their memory, and recall instances when candidates they supported were winners.

The important point for our analysis is that we have a group of respondents who identify themselves as losers in the electoral arena and who were randomly assigned different versions of our questions asking about institutional change. Moreover, cross tabulations of perceptions of winning and losing by party affiliation give evidence for the validity of our measures of losing: Democrats were significantly more likely than Republicans to report being losers in past presidential elections $\left(\chi^{2}=21, p<0.000\right)$ and were more likely to expect to lose in the future $\left(\chi^{2}=23, p<0.000\right)$. This is consistent with the fact that Democratic candidates lost four of the six presidential contests prior to the survey, and with Democrats losing the US House, Senate and presidential elections in the year following our survey. Partisan differences were not significant in responses to the question about congressional elections $\left(\chi^{2}=4, p>0.40\right)$, which is consistent with the fact that the parties'

$\stackrel{2 n}{\rightarrow}$ Gerald C. Wright, 'Misreports of the Vote in the 1988 Senate Election Study', Legislative Studies Quarterly, 15 (1990), 543-63. 


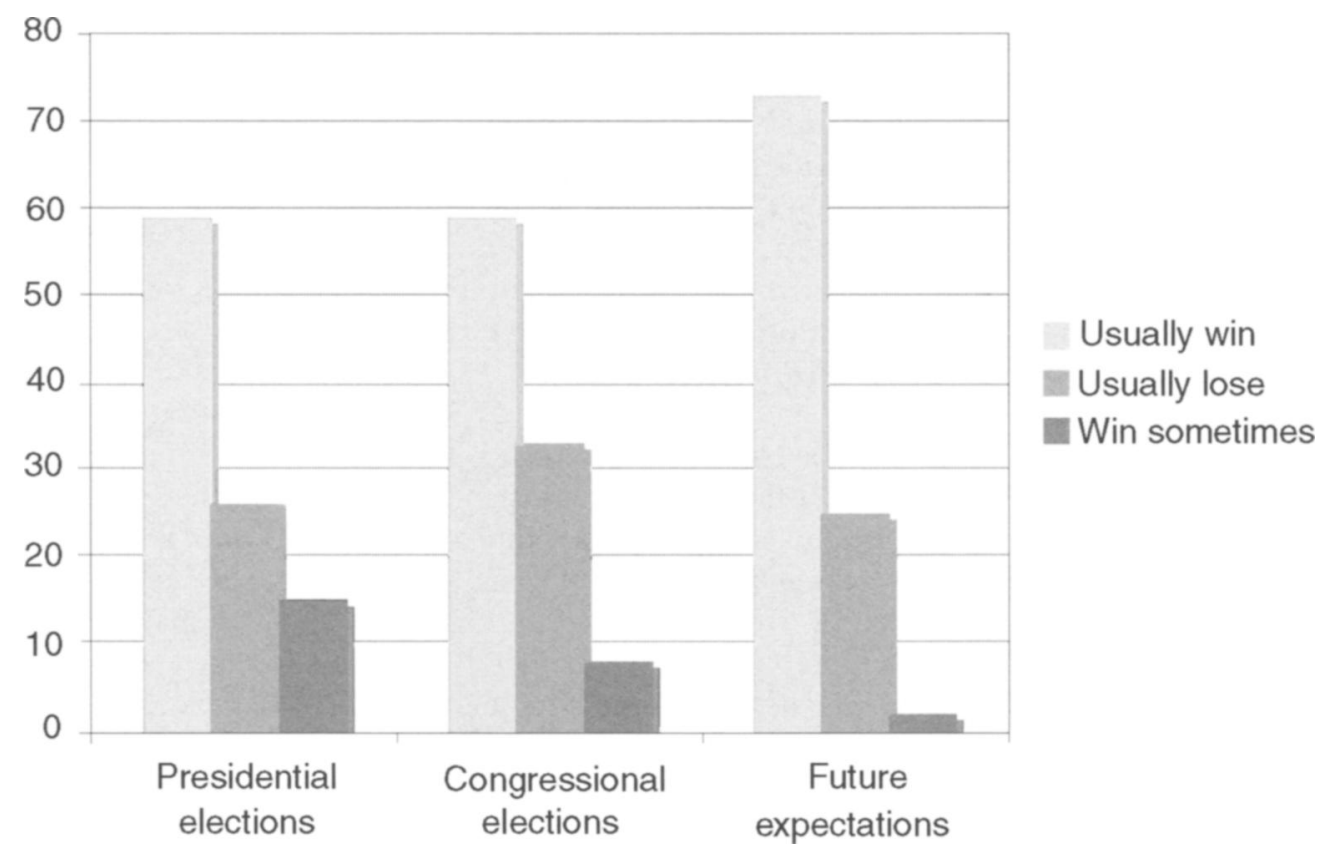

Fig. 1. Perceptions of electoral wins and losses in the United States

Source: Author's survey conducted by Indiana University Center for Survey Research. National sample, random digit dial, conducted October through November 2003.

Note: For the first two questions, respondents were asked, 'Think about the [presidential/congressional] elections held in your lifetime. Do you think that the [presidential/congressional] candidates you support usually win, or usually lose?' The third question asked, 'Looking ahead to any upcoming local, state, or national elections - how do you think most of the candidates you support will do?' Some respondents volunteered that they 'sometimes win'. $N=694$ cases for the presidential question, 688 for the congressional question and 668 for expectations.

control of the US Congress was largely balanced in the years prior to our survey. ${ }^{31}$ Again, we are concerned not so much about the accuracy of perceptions of losing but about how people who perceive themselves as losers or winners differ in how they reason about proposals to change institutions.

Table 2 reports descriptive data illustrating differences in support for reform proposals across electoral winners and losers. It lists the percentage of respondents supporting the four electoral reform proposals we asked about: imposing term limits on Congress, establishing a national referendum process, direct election of the president and proportional representation (PR) for Congress. Levels of support for each proposal is listed for winners and losers - classified in terms of their self-reported perceptions.

We find that a majority of electoral winners and majority of electoral losers were in favour of changing to direct presidential elections, imposing term limits on Congress and establishing provisions for a national referendum process. Majorities of losers were supportive of proportional representation, while majorities of winners were opposed. Our

31 Democrats controlled the House and Senate for decades until 1995, broken by a period of Republican control of the Senate from 1981 to 1987. Republicans controlled both chambers from much of 1995 through 2005, with neither party having more than 51 per cent of Senate seats from 2001 to 2004. 
TABLE 2 Attitudes about Electoral Reform in the United States by Respondent's Status as a Loser in the Electoral Arena

\begin{tabular}{|c|c|c|c|c|c|c|}
\hline & \multicolumn{2}{|c|}{$\begin{array}{l}\text { Usually supports } \\
\text { presidential } \\
\text { candidates who: }\end{array}$} & \multicolumn{2}{|c|}{$\begin{array}{l}\text { Usually supports } \\
\text { congressional } \\
\text { candidates who: }\end{array}$} & \multicolumn{2}{|c|}{$\begin{array}{l}\text { Expectations about } \\
\text { how candidates } \mathrm{R} \\
\text { supports will do } \\
\text { in future: }\end{array}$} \\
\hline & Win & Lose & Win & Lose & Win & Lose \\
\hline $\begin{array}{l}\text { Satisfied with the way } \\
\text { democracy works }\end{array}$ & $\begin{array}{c}88 \% \\
(513) \\
p=\end{array}$ & $\begin{array}{l}68 \% \\
(174) \\
000\end{array}$ & $\begin{array}{c}87 \% \\
(464) \\
p<\end{array}$ & $\begin{array}{l}75 \% \\
(220) \\
001\end{array}$ & $\begin{array}{l}86 \% \\
(501) \\
\quad p\end{array}$ & $\begin{array}{l}73 \% \\
(165) \\
.000\end{array}$ \\
\hline $\begin{array}{l}\text { Support term limits } \\
\text { on Congress }\end{array}$ & $\begin{array}{l}74 \% \\
(505)\end{array}$ & $\begin{array}{l}71 \% \\
(173)\end{array}$ & $\begin{array}{l}72 \% \\
(458)\end{array}$ & $\begin{array}{l}77 \% \\
(217)\end{array}$ & $\begin{array}{l}73 \% \\
(494)\end{array}$ & $\begin{array}{l}74 \% \\
(163)\end{array}$ \\
\hline $\begin{array}{l}\text { Support a national } \\
\text { referendum process }\end{array}$ & $\begin{array}{l}72 \% \\
(505)\end{array}$ & $\begin{array}{l}74 \% \\
(172)\end{array}$ & $\begin{array}{l}72 \% \\
(455)\end{array}$ & $\begin{array}{l}74 \% \\
(217)\end{array}$ & $\begin{array}{l}71 \% \\
(493)\end{array}$ & $\begin{array}{l}73 \% \\
(162)\end{array}$ \\
\hline $\begin{array}{l}\text { Support direct } \\
\text { election of the } \\
\text { President }\end{array}$ & $\begin{array}{l}52 \% \\
(507)\end{array}$ & $\begin{array}{l}57 \% \\
(169)\end{array}$ & $\begin{array}{l}53 \% \\
(455)\end{array}$ & $\begin{array}{l}53 \% \\
(215)\end{array}$ & $\begin{array}{l}51 \% \\
(498)\end{array}$ & $\begin{array}{l}58 \% \\
(158)\end{array}$ \\
\hline $\begin{array}{l}\text { Support proportional } \\
\text { representation for } \\
\text { Congress }\end{array}$ & $\begin{array}{c}44 \% \\
(485) \\
p<\end{array}$ & $\begin{array}{l}58 \% \\
(160) \\
02\end{array}$ & $\begin{array}{l}46 \% \\
(434)\end{array}$ & $\begin{array}{l}50 \% \\
(207)\end{array}$ & $\begin{array}{c}44 \% \\
(470) \\
p\end{array}$ & $\begin{array}{l}59 \% \\
(158) \\
.001\end{array}$ \\
\hline
\end{tabular}

Source: Author's survey conducted by Indiana University Center for Survey Research. National sample, random digit dial, conducted October through November 2003.

Note: Entries are percentage agreeing strongly or very strongly with the proposal for change, and the percentage satisfied or very satisfied with democracy in the United States. Significance based on $\chi^{2}$ tests. Values in parentheses are total number of respondents in category of winner/loser.

initial expectation (see Hypothesis 1 above) was that losers would be consistently more supportive of proposals for institutional change, regardless of how the proposal was framed. Consistent with Hypothesis 1, we find higher support for changing US House elections to PR among losers (58 per cent) than winners (44 per cent). We find, however, that losers were just slightly more supportive of changing how the president is elected than winners were ( 57 to 52 per cent) and were only slightly more likely than winners to support term limits ( 77 to 72 per cent). The evidence in Table 2 provides some support for Hypothesis 1, but the results are clearly mixed. In some cases there were trivial differences between winners' and losers' attitudes about electoral reform proposals. Of course, these data in Table 2 do not account for how the risk of adopting the reforms was framed. The experiments reported below allow us to test whether the data in Table 2 overstate support for change among electoral winners and losers by testing additional hypotheses that are at the heart of our experimental analysis. That is, how do winners and losers' attitudes about these reform proposals shift when they are given other factors to consider?

The descriptive data in Table 2 also demonstrate that losers in America, no matter how defined, are less satisfied with how democracy works than winners. Satisfaction with 
democracy is 20 per cent lower among Americans who see themselves as regularly being on the losing side of presidential elections. In a study of Europe, Anderson et al. found that this inverse relationship between electoral loss and satisfaction with democracy existed in unitary and federal systems alike, as well as in nations with single-party or multi-party governments - but dissatisfaction among losers was greatest in unitary systems and in nations where one party formed the government. ${ }^{32}$ Despite effects that federalism may have on dampening the consequences of electoral loss, our data illustrate that perceptions of electoral loss nonetheless have substantial effects on attitudes about how well democracy functions in the United States.

We are interested in how these perceptions of electoral loss affect evaluations of democracy and how they affect people's reasoning about changing democratic arrangements. That is, do considerations of electoral prospects weaken the mass public's satisfaction with democracy? Are evaluations of democracy malleable enough to be affected by short-term considerations of electoral loss? Do considerations of risk associated with institutional change affect winners and losers the same way? We turn now to the experiments to answer these questions.

\section{Do Considerations of Electoral Losses Affect How Satisfied People Are with the Way Democracy Works?}

We tested this by randomly assigning half of respondents the satisfaction with democracy question before offering them our three questions about winning and losing, and by assigning the other half the satisfaction item immediately after asking the three questions about winning and losing. Table 3 reports levels of satisfaction with democracy (percentage very satisfied + percentage satisfied), for electoral winners and losers randomly assigned to each experimental condition. Respondents are classified as winners and losers based on their responses to the three electoral loss questions. Those who responded as winners on at least two of the three questions (presidential elections, congressional elections and future expectations) are classified as winners. Those who responded as losers on at least two of the three questions are classified as losers.

Results of this experiment reported in Table 3 illustrate that electoral losers may become even less satisfied with democracy when they are prompted to consider how often they lose. This suggests that other studies making use of secondary survey measures of losing (reported vote) may understate the effects of losing, as such studies do not prompt respondents to consider that they have lost. We also find slightly higher levels of satisfaction with democracy among winners if they were asked the satisfaction question after being prompted with questions that made them consider how often their candidates win or lose. We find a much larger effect among losers - there is less satisfaction with democracy among losers who were asked to evaluate democracy immediately after being prompted to consider the electoral success of their candidates. That is, 69 per cent of losers reported being satisfied with democracy when they were not prompted to consider whether candidates they support win or lose. Satisfaction with democracy among losers drops to 62 per cent among those prompted to consider whether candidates they support usually win or lose. The total effect of being prompted to consider wins and losses amounts to a 9 per cent change in levels of satisfaction: a 2.1 per cent increase in satisfaction with

${ }^{32}$ Anderson et al., Losers' Consent. 
TABLE 3 Experimental Results: Consideration of Electoral Losses Erodes

Satisfaction with Democracy among Losers

\begin{tabular}{|c|c|c|c|}
\hline & \multicolumn{3}{|c|}{ Respondent's status } \\
\hline & Winner & Loser & Net difference \\
\hline $\begin{array}{l}\text { Asked satisfaction with democracy before } \\
\text { three questions about electoral losses }\end{array}$ & $86.4 \%(272)$ & $68.9 \%(89)$ & \\
\hline $\begin{array}{l}\text { Asked satisfaction with democracy after } \\
\text { three questions about electoral losses } \\
\text { Percentage point difference }\end{array}$ & $\begin{array}{l}88.5 \%(279) \\
+2.1\end{array}$ & $\begin{array}{l}62.0 \%(58) \\
\quad-6.9\end{array}$ & $9.0 \%$ \\
\hline & Big winner & Loser & Net difference \\
\hline $\begin{array}{l}\text { Asked satisfaction with democracy before } \\
\text { three questions about electoral losses }\end{array}$ & $86.8 \%(167)$ & $68.9 \%(89)$ & \\
\hline $\begin{array}{l}\text { Asked satisfaction with democracy after } \\
\text { three questions about electoral losses }\end{array}$ & $91.4 \%(163)$ & $62.0 \%(58)$ & \\
\hline Percentage point difference & +4.6 & -6.9 & $11.5 \% \ddagger$ \\
\hline
\end{tabular}

Source: Author's survey conducted by Indiana University Center for Survey Research. National sample, random digit dial, conducted October through November 2003.

Note: Cell entries are percentage who responded that they were very satisfied or satisfied with democracy, with the total number of subjects per subgroup in parentheses. 'Winner' are those who classified themselves as winners on at least two of the three questions; losers are those coded as losers on at least two of the three questions used to measure losing. Big winners are those classified as winners on all three questions.

Significance of differences between groups is derived from a logistic regression equation, where the individual's response to the satisfaction with democracy question $(1=$ satisfied/very satisfied, $0=$ dissatisfied/very dissatisfied) is predicted as a function of dummy variable representing being a winner asked the question before the loss prompt, or a loser asked after the loss prompt.

$¥$ Significant difference between winners and losers across response to risk frame $(p=0.12)$.

democracy among winners, and a 6.9 per cent decline in satisfaction among losers. This is consistent with our initial expectation (Hypothesis 2) discussed above. Table 3 also compares big winners (those who never respond as a loser on our three measures) to losers. We find a larger increase in satisfaction among big winners who were asked to evaluate democracy after considering their history of wining and losing, with the total effect of the prompt to be 11.5 per cent when big winners are compared to losers.

To put these results into better perspective, electoral losers have lower levels of satisfaction to start with, but their satisfaction erodes even further when they consider how well their candidates fare in elections. The winner-loser gap in satisfaction with democracy becomes quite striking when the effect of being a winner or loser is combined with the effect of being prompted to consider electoral wins and losses. As illustrated in Table 3, we see that 88.5 per cent of American winners reported being satisfied with democracy when asked that question after considering how well their candidates fare in elections. In contrast, only 62 per cent of losers reported being satisfied after considering how well their candidates do - a 26.5 per cent gap in levels of satisfaction with democracy. The gap is even larger (29.4 per cent) when big winners are compared to losers. 
Evaluations of how well democracy works thus appear to be highly sensitive to the effects of winning and losing, and, on top of this, to prompts that remind people about their wins and losses. Considerations of wins and losses appear to have different effects for winners and loser; making winners more satisfied and losers less so. Our next experiments were designed to test whether electoral winners and losers also reason differently about proposals to change democratic institutions. Specifically, we test whether support for change is sensitive to potential risks associated with change, and whether sensitivity to risks of loss affects winners and losers the same way.

\section{Does Aversion to Risk Reduce Support for Institutional Change? Are Losers Less Risk Averse when Reasoning about Changing Institutions?}

The risk aversion theory discussed above led us to expect that the answers to all of these questions are 'Yes' (see Hypotheses 3 and 4 above). We used the CATI platform to structure four $2 \times 2$ experiments related to the questions above. The results of the first three are presented in Tables 4 and 5. The results of the last are reported in Table 6. In each of the $2 \times 2$ 's in these tables, the upper left-hand cells represent people in condition (A) from our hypotheses described in Table 1; people in condition (B) are represented in the upper right-hand cells, condition (C) in the lower left-hand cells, and condition (D) by the lower right-hand cells.

These experiments were designed to advance our understanding of how citizens reason when considering proposals to alter democratic institutions. As noted above, respondents were randomly assigned a version of each of the four questions about electoral reform. The question wording was alternated to frame each proposal either as a loss, or as a gain (or neutral). For example, one version of the term limits question asked: 'Some people suggest that there should be term limits on members of Congress - so incumbents could only run for re-election three or four times. This might give new candidates a better chance to gain office. Would you support such a proposal?' The alternative version framed the proposal as a risk of loss by including the same initial sentence, but replaced the sentence about 'gaining office' with, 'This might mean losing some of the most experienced members in Congress.' Similar wording variation was used to present risky and non-risky versions of each proposal.

In Table 4, winners and losers are classified in terms of their responses to the question about congressional elections (since the reform proposals would affect how Congress functions). The point of the tables is to allow comparisons of support for each institutional change depending on whether the proposal was presented in terms of the risk of a loss or not. Reading down the first column of numbers we can see if support for each proposal among winners shifted when it was presented as a risk of a loss. Reading down the second column, we see whether support for institutional change shifted when the risk of loss version of the proposal was presented to losers.

Table 4 illustrates that the experimental results for winners largely match our a priori theoretical expectations set out in Hypothesis 3. The decline in support for change among winners produced by framing a proposal as a loss was statistically significant in two of three tests. Winners were much less supportive of the referendum proposal and the term limits proposal when these reforms were framed as having a risk of some loss. The risk frame had a negligible effect on winners' support for PR, however. In Table 5 we report results of the same experiments, but with winners and losers classified in terms of their future expectations about winning and losing. In Table 5 we see that winners' support for a 
TABLE 4 Experimental Results: Perceptions of Electoral Loss and Risk Aversion

\begin{tabular}{lccc}
\hline \hline & \multicolumn{2}{c}{ Respondent's status } & $\begin{array}{c}\text { Net diff. in } \\
\text { effect of } \\
\text { framing } \\
\text { as loss }\end{array}$ \\
\cline { 2 - 3 } Stimulus & Winners & Losers & \\
\hline Term limits on Congress (framed as gain) & $80.4 \%(235)$ & $86.6 \%(112)$ & \\
Term limits on Congress (framed as loss) & $63.2 \%(223)$ & $66.7 \%(105)$ & \\
Percentage point difference & $-17.2^{* *}$ & $-19.9 * *$ & $-2.7 \%$ \\
National referendum (framed as gain) & $79.0 \%(220)$ & $74.6 \%(122)$ & \\
National referendum (framed as loss) & $65.1 \%(235)$ & $73.7 \%(95)$ & \\
Percentage point difference & $-13.9 * *$ & -0.9 & $14.8 \% *$ \\
PR for Congress (neutral frame) & $47.0 \%(223)$ & $46.1 \%(102)$ & \\
PR for Congress (framed as loss) & $46.0 \%(211)$ & $54.3 \%(105)$ & \\
Percentage point difference & -0.9 & $+8.2 \dagger$ & $9.1 \% \ddagger$ \\
\hline \hline
\end{tabular}

Source: Author's survey conducted by Indiana University Center for Survey Research. National sample, random digit dial, conducted October through November 2003.

Note: Cell entries are percentage who agree strongly or very strongly with the proposal for change, with the number of subjects per subgroup in parentheses. Losers are identified by responses to the question about congressional elections.

Significance between experimental groups is derived from a logistic regression equation, where the individual's response to a question about institutional change $(1=$ strongly agree/agree, $0=$ disagree/strongly disagree) is predicted as a function of the question version $(\mathrm{B}$, the risky version $=1$, version $\mathrm{A}=0)$, being a loser $(1=$ reports usually supporting losing congressional candidates, $0=$ other), and an interaction term (question version $\mathrm{B} \times$ loser), with controls for gender, partisanship, ideology and age. The interaction tests whether losers' sensitivity to the risky version of a question about institutional change is significantly different from winners'. *Significant difference between groups of winners and losers in response to the risk frame (reading across, $p<0.05$ ).

**Significant differences within group (reading down, $p<0.05$ ), based on $Z$ score calculating significance of difference between proportions.

$\dagger$ Significant differences within group (reading down, $p<0.12$ ), based on $Z$ score calculating significance of difference between proportions.

$\ddagger$ Significant difference between winners and losers in response to risk frame (reading across, $p=0.11)$.

national referendum process dropped 11 percentage points when the proposal was presented as a risk, while winners' support for term limits dropped by 20 percentage points when the proposal is framed as a risk. Support for each proposal was thus consistently lower among winners who were presented the risky version of the reform proposal.

However, contrary to our initial expectation (Hypothesis 3), framing the proposal in terms of a loss did not always decrease support for institutional change among all respondents. Support for the PR proposal among losers (defined in terms of congressional elections or their future expectations) did not decline when the proposal was framed as the prospect of a loss. In fact, with the PR for Congress proposal, support among losers in Table 4 and Table 5 increased significantly when they were presented with the more risky version of the proposal.

Results displayed in Table 4 and Table 5 are, on balance, consistent with our expectation (Hypothesis 4) that losers are less sensitive to the risk of loss associated with institutional changes. This effect can be seen in the net difference between winners' and losers' 
TABLE 5 Experimental Results: Expectations about Electoral Loss and Risk Aversion

\begin{tabular}{|c|c|c|c|}
\hline \multirow[b]{2}{*}{ Stimulus } & \multicolumn{2}{|c|}{ Respondent's status } & \multirow{2}{*}{$\begin{array}{l}\text { Net diff. in } \\
\text { effect of } \\
\text { framing } \\
\text { as loss }\end{array}$} \\
\hline & Winners & Losers & \\
\hline Term limits on Congress (framed as gain) & $82.5 \%(252)$ & $79.6 \%(88)$ & \\
\hline Term limits on Congress (framed as loss) & $62.4 \%(242)$ & $68.0 \%(75)$ & \\
\hline Percentage point difference & $-20.1 * *$ & $-11.6 * *$ & $8.5 \% \ddagger$ \\
\hline National referendum (framed as gain) & $77.2 \%(250)$ & $77.6 \%(85)$ & \\
\hline National referendum (framed as loss) & $66.6 \%(243)$ & $68.9 \%(77)$ & \\
\hline Percentage point difference & $-10.6 * *$ & -8.7 & $1.9 \%$ \\
\hline PR for Congress (neutral frame) & $44.9 \%(245)$ & $51.4 \%(72)$ & \\
\hline PR for Congress (framed as loss) & $42.2 \%(225)$ & $65.1 \%(86)$ & \\
\hline Percentage point difference & -2.7 & $+13.7 * *$ & $16.7 \% *$ \\
\hline
\end{tabular}

Source: Author's survey conducted by Indiana University Center for Survey Research. National sample, random digit dial, conducted October through November 2003.

Note: Cell entries are percentages who agree strongly or very strongly with the proposal for change, with the total number of subjects per sub-group in parentheses. Losers are identified by responses to the question on their expectations about future elections.

Significance of differences between groups is derived from a logistic regression equation, where the individual's response to a question about institutional change $(1=$ strongly agree/agree, $0=$ disagree/strongly disagree) is predicted as a function of the question version $(\mathrm{B}$, the risky version $=1$, version $\mathrm{A}=0)$, being a loser $(1=$ expects to lose in future, $0=$ other $)$, and an interaction term (question version $\mathrm{B} \times$ loser), with controls for gender, partisanship, ideology and age. The interaction tests whether losers' sensitivity to the risky version of a question about institutional change is significantly different from winners'.

* Significant difference between winners and losers in response to the risk frame (reading across, $p<0.05$ ).

**Significant differences within group (reading down, $p<0.05$ ), based on $Z$ score calculating significance of difference between proportions.

$\ddagger$ Significant difference between winners and losers in response to risk frame (reading across, $p=0.14)$.

responses to proposals that are framed as a risk of loss (this value is listed in the third column of each table). In Table 4, we find that support for a national referendum declined significantly more among winners in response to the framing effect than among losers (a net difference of 14.8 points). In Table 5, we find that winners' support for term limits also declined significantly more than losers' support did in response to the risk frame (a net difference of 8.5 points). With the PR proposal, shifts in losers' attitudes were also significantly less risk aversive than the shift in winners' attitudes.

Thus, in three of the six tests reported in Tables 4 and 5, winners appear to be more risk aversive to electoral system change than losers. In two other tests, losers might actually be seen as risk seeking. We find losers more risk aversive than winners in just one of the six tests. In terms of our schematic hypotheses presented in Table 1, support for reforms among subjects in Group $C$ was consistently lower than support among subjects in Group $\mathrm{D}$, and in most cases $(\mathrm{A}-\mathrm{C})>(\mathrm{B}-\mathrm{D})$. The effect of being a loser assigned the risk frame was significant in four of six experiments reported in Tables 4 and 5 . Logit models estimating support across all respondents for a national referendum and 
for PR find significantly higher support among congressional losers assigned the version of reform questions framed as a loss (with loser status and question version held constant). These results remain significant when age, ideology, gender and partisanship are accounted for. Similar models estimating support for term limits and PR find that respondents expecting to lose in the future who were assigned the question framed as a loss were also significantly more supportive of those reforms.

Table 6 reports a final experiment designed to evaluate how winners and losers reason about changing electoral rules. As the Appendix illustrates, our questions about changing how the US president is elected were framed differently from the other three electoral reform proposals. Where the other experiments framed risks without making explicit reference to who is made better or worse off, alternative versions of our Electoral College question provided respondents with a cue about who might win or lose if the proposal were adopted..$^{33}$ One version framed this cue as a potential gain: 'states with large populations could have more influence' if the president were elected by direct popular vote. The alternative version framed the cue as a potential loss: 'states with small populations could have less influence'. This framing is closer to the logical equals used in classic tests of risk aversion $^{34}$ and it also allows for an experiment where respondents can be classified as winners or losers based on whether they would benefit or be harmed by a change in the status quo. Again, half of all respondents were randomly assigned the proposal framed either as a gain (more influence) or a loss (less influence).

In Table 6, we once again divided our sample to classify respondents as winners and losers. In this analysis, subjects who lived in states with average or below-average numbers of Electoral College votes were classified as winners, as they benefited from status quo arrangements that over-represent their states in the existing presidential election process. These were people living in states with twelve or fewer electoral votes. ${ }^{35}$ We assume that losers under status quo arrangements are those living in the largest states (having twenty-one or more electoral votes - but far less representation per person). ${ }^{36}$

Results in Table 6 are consistent with our initial expectations (see Hypotheses 3 and 4). Reading across the top row, we see that when the proposal to change to direct election of the president was framed as a gain ('large states have more influence'), there was a relatively small difference in support for reform between those who were winners or losers under the Electoral College status quo. Curiously, slightly more status quo winners (small

${ }^{33}$ Recall that the Electoral College over-represents states with smaller populations, at the expense of states with larger populations.

34 Kahneman and Tversky, 'Prospect Theory'; Kahneman and Tversky, 'Choices, Values, and Frames'.

35 The average state had eleven EC votes, with the median value being eight.

${ }^{36}$ In populous states (twenty-one EC votes or more) on average there were 600,000 people represented per EC vote. In smaller and median-size states (fewer than twelve EC votes), on average there were 400,000 people represented per EC vote. Given this mallapportionment, and that geographic dispersion of presidential campaign activity in states was inversely related to state population (see http://www.fairvote.org/whopicks/), we assume it is valid that people in large (small) states might perceive they lose (win) under this status quo. This assumption may be suspect: formal game theoretic logic demonstrates that under certain conditions voters in larger states can have a greater chance of playing a 'pivotal' role in presidential election outcomes. For a review, $\rightarrow$ Bernard Grofman and Scott L. Feld, 'Thinking about the Political Impacts of the Electoral College', Public Choice, 123 (2005), 1-18. These formal models make assumptions about states as actors in coalition formation games that may not be consistent with the perceptions of actual voters. Moreover, the question was designed to prompt voters to consider that large (small) states would have more (less) influence under the proposed reforms, so we are able to test the effect of that prompt. 
TABLE $6 \quad$ Experimental Results: Risk Aversion and Reasoning about Proposals where Winners and Losers are Specified

\begin{tabular}{lccc}
\hline \hline & $\begin{array}{c}\mathrm{R} \text { winning under } \\
\text { status quo rules } \\
\text { (R lives in average } \\
\text { or small state) }\end{array}$ & $\begin{array}{c}\text { R losing under } \\
\text { status quo rules } \\
\text { (R lives in a } \\
\text { (large state) }\end{array}$ & $\begin{array}{c}\text { Net difference } \\
\text { in effect of } \\
\text { framing as } \\
\text { risk of loss }\end{array}$ \\
\hline $\begin{array}{l}\text { Direct election of president means } \\
\text { large states have more influence } \\
\text { (framed as gain) }\end{array}$ & $57 \%(166)$ & $52 \%(112)$ & \\
$\begin{array}{l}\text { Direct election of president means } \\
\text { small states have less influence } \\
\text { (framed as loss) }\end{array}$ & $\begin{array}{c}46 \%(152) \\
-11^{* *}\end{array}$ & $\begin{array}{c}60 \%(150) \\
+8 \dagger\end{array}$ & $19 \% *$ \\
\hline \begin{tabular}{l} 
Percentage point difference \\
\hline \hline
\end{tabular}
\end{tabular}

Source: Author's survey conducted by Indiana University Center for Survey Research. National sample, random digit dial, conducted October through November 2003.

Note: Cell entries are percentage who agree strongly or very strongly with the proposal for change, with the total number of subjects per subgroup in parentheses. Subjects are classified by how many Electoral College votes their state controls. Large states are those with 21 or more, small are those with less than 12 .

Significance between groups is determined by a logistic regression equation, where the individual's response to the Electoral College question $(1=$ strongly agree/agree, $0=$ disagree/ strongly disagree) is predicted as a function of question version $(B$, the risk version $=1$, version $\mathrm{A}=0)$, residing in a large state $(1=$ large state, $0=$ other), and an interaction term (question version $\mathrm{B} \times$ large state), with controls for gender, age, ideology and partisanship. The interaction tests if a large state respondent's sensitivity to the risk version of the Electoral College question is significantly different from a small state respondent.

*Significant difference between winners and losers response to the risk frame (reading across, $p<0.05)$.

**Significant differences within group (reading down, $p<0.05$ ), based on $Z$ score calculating significance of difference between proportions.

$\dagger$ Significant differences within group (reading down, $p<0.10$ ), based on $Z$ score calculating significance of difference between proportions.

state residents) favoured this change that could dilute their influence. Fifty-seven per cent of small state residents favoured changing to direct election when the proposal was framed as a gain. This compares to 52 per cent of status quo losers who supported the proposal when it was presented as a gain. When framed as a gain then, we see minor differences in levels of support across people who win or lose under existing rules - and it appears winners were slightly more enthusiastic about changing the rules than losers.

The pattern reverses, however, when this reform proposal was framed as a loss ('small states have less influence'). This shift in winners' attitudes provides further evidence that winners and losers respond differently to risk. When direct election of the president is framed as a potential loss, only 46 per cent of status quo winners favoured change, a decline of 11 percentage points compared to winners who were presented with the alternative frame. Once again, we find that people who are winners under the status quo were much less supportive of the proposal when it was framed as a loss. Losers, in contrast, became more supportive when the proposed change in presidential election rules was framed as a loss. Whereas losers were less supportive of change even than winners when the proposal 
was framed as gain, losers' support for changing to direct elections increased by 8 points (to 60 per cent) among those exposed to the risk frame.

Thus we see again that winners are more risk averse than losers when reasoning about proposals to change electoral arrangements, but we also see that losers, beyond simply being neutral in their response to risk of loss, can be risk acceptant. The net result of this effect in responding to the risk framing is a substantial 19 point shift in attitudes about how the president should be elected: an 8 point increase in support for direct elections among losers associated with their response to risk, plus an 11 point decline in support for direct presidential elections among winners due to their response to risk.

\section{DISCUSSION}

Our survey found rather high levels of support for proposals to change electoral institutions in the United States, and we also found that people who see themselves as losers in the electoral arena are less satisfied with how well democracy works. At first glance this suggests that there may be a large constituency in the American mass public who are receptive to proposals to change electoral institutions. That said, we know that America's national electoral institutions, like those of Britain and Canada, are quite stable historically and have proven to be resistant to structural change. Hence the paradox we presented at the start of this essay: if most voters often support losing candidates, and proposals for electoral system change are relatively popular, why are electoral institutions so stable? We can take this a bit farther: if reforms are embraced by losers and winners alike why are electoral institutions so stable?

There are several possible answers to these questions, and we believe our experimental findings offer some insight into how the mass public may act - like elites - as a force for stability in political institutions. First, the framing effects displayed in our experiments illustrate that relatively high levels of support for institutional change found among those who win under status quo electoral arrangements can be quite ethereal. When winners were prompted to consider that a reform might come at some cost, their support for reform declined. This was not always the case, however, with losers. In some of these experiments, losers appeared relatively insensitive to risks associated with changing democratic institutions. At times, they accepted risk. Winners, in contrast, appear much more sensitive to such risks. In other words, it appears that people are able to sort out how changes in political institutions might make them better or worse off, and winners and losers reason differently with this information. When people who are doing well under status quo institutions realize that there is a risk of loss from institutional change, they are less supportive of change. When people who are doing less well under status quo institutions realize that there are risks of loss associated with change, their support for change may remain firm, or even increase. These effects are rather impressive when we consider that most of these proposals provided no cues about who the winners and losers would be.

Secondly, the stability of electoral institutions may result from the fact that few Americans perceive themselves as consistently ending up on the losing side of most elections. It is possible that these perceptions are rooted in reality, at least in America. Given the federal nature of America's election system, and the frequency of elections over time, few people may end up as chronic electoral losers. Thirdly, and related to this second point, people may actually vote for losing candidates quite often, yet discount most of the electoral losses they experience, or they may somehow place greater weight on their wins. This point is analogous to what psychologists refer to as the partial reinforcement effect, 
where behaviours with satisfying consequences (winning) are strengthened and remembered even if the satisfying consequence does not occur regularly. Put differently, people might vote regularly (for the same type of candidates) and lose rather often. However, if their electoral system allows them to win at least occasionally, those wins could outweigh regular losses in structuring their behaviour and memory - so they may perceive themselves as winners. And, as we demonstrated above, support for institutional change can be fairly transient among people who perceive themselves as electoral winners.

Fourthly, rules are clearly designed to insulate electoral institutions from electoral loser's preferences. As North notes, institutions themselves, rather than moving inexorably towards efficiency, tend to evolve towards preserving the status of those who make the rules. ${ }^{37}$ As example, the US Constitution regulates rules about the election of the president, and reserves the power to adopt term limits for Congress to Congress itself. Even institutions that can be changed by statute (such as PR for the US House, or some form of a national referendum process), are regulated by the actors who won office under existing rules. Clearly, it is difficult to amend the Constitution or pass statutes without action on the part of electoral winners. Studies show these elites, not surprisingly, are less supportive of institutional change than their unsuccessful electoral opponents.

Institutional changes are also inherently risky, and the uncertainty attached to changes makes the whole process of change more complicated than a story grounded in rational self-interest may allow. Not only that, the risks associated with change may also make change less likely. Here, however, we have found evidence that losers may not find the risks associated with change as motivating a reason to oppose change. Although appeal to the risks of change may dampen winners' support for reforms, appeals to risk may not dissuade losers from wanting change. If anything, losers may be willing to gamble. This suggests that if actual institutional reform proposals do reach the public agenda, even relatively sweeping proposals may be looked on with favour by losers. The difference between institutional stability and change may then depend upon how many people perceive themselves as losers.

\section{APPENDIX: SURVEY ITEMS}

\section{Term Limits}

Version A: Some people suggest that there should be term limits on members of Congress - so incumbents could only run for re-election three or four times. This might give new candidates a better chance to gain office. Would you support such a proposal?

Version B: Some people suggest that there should be term limits on members of Congress - so incumbents could only run for re-election three or four times. This might mean losing some of the most experienced members in Congress. Would you support such a proposal?

\begin{tabular}{|l|l|l|}
\hline Yes, support & No, oppose & DK/refused \\
\hline
\end{tabular}

\section{Direct Democracy}

Version A: There is a proposal for a national referendum to permit voters to approve or reject some federal laws. An issue would be placed on the ballot if a large number of voters from around the country signed a petition. Would you support this proposal to give voters a direct say in making laws?

${ }^{37}$ North, Institutions, Institutional Change and Economic Performance. 
Version B: There is a proposal for a national referendum to permit voters to approve or reject some federal laws. An issue would be placed on the ballot if a large number of voters from around the country signed a petition. Would you support this proposal to give voters a direct say in making laws even if it would undermine the independent judgment of elected officials?

\begin{tabular}{|l|l|l|}
\hline Yes, support & No, oppose & DK/refused \\
\hline
\end{tabular}

\section{Electing the President}

Version A: When it comes to electing the President, some suggest we get rid of the Electoral College and simply elect the candidate who most people voted for. This would mean that states with large populations could have more influence over who wins. Would you support or oppose such a proposal?

Version B: When it comes to electing the President, some suggest we get rid of the Electoral College and simply elect the candidate who most people voted for. This would mean that states with small populations could have less influence over who wins. Would you support or oppose such a proposal?

\begin{tabular}{|l|l|l|}
\hline Yes, support & No, oppose & DK/refused \\
\hline
\end{tabular}

\section{Election of Congress}

Version A: Some people suggest we should use proportional representation to elect Congress. This would probably mean that three or more parties would be represented in Congress. Would you support such a proposal?

Version B: Some people suggest we should use proportional representation to elect Congress. This would probably mean that three or more parties would be represented in Congress, and could mean that no single party would form a majority. Would you support such a proposal?

\begin{tabular}{|c|c|c|}
\hline Yes, support & No, oppose & DK/refused \\
\hline
\end{tabular}

\section{Measures of Perceptions of Electoral Loss}

(A) Think of the presidential elections held in your lifetime. Do you think that the presidential candidates you support:

\begin{tabular}{|l|l|l|l|}
\hline Usually win & Usually lose & Sometimes win or sometimes lose & Don't know \\
\hline
\end{tabular}

(B) Think of the elections for US Congress held in your lifetime. Do you thing that the congressional candidates you support:

\begin{tabular}{|l|l|l|l|}
\hline Usually win & Usually lose & Sometimes win or sometimes lose & Don’t know \\
\hline
\end{tabular}

(C) Looking ahead to any upcoming local, state, or national elections - how do you think most of the candidates you support will do? Do you think:

\begin{tabular}{|l|l|l|l|}
\hline Most of them might win & Most might lose & Some might win, some lose & Don't know \\
\hline
\end{tabular}




\section{Satisfaction with Democracy}

(Note: The placement of these measures of losing was rotated so that half the sample was asked them prior to the satisfaction with democracy item (below), and half were asked this prior to the three questions on losing (above).)

On the whole, how satisfied are you with the way democracy works in the US? Would you say very, fairly, not very or not at all satisfied?

\begin{tabular}{|c|c|c|c|c|}
\hline Very satisfied & Fairly satisfied & Not very satisfied & Not at all satisfied & DK/Refused \\
\hline
\end{tabular}

